\title{
Phenotypic, Stress Tolerance and Plant Growth Promoting Characteristics of Rhizobial Isolates from Selected Wild Legumes of Semiarid Region, Tirupati, India
}

\author{
Y. Bhargava1, J. S. R. Murthy ${ }^{2}$, T. V. Rajesh Kumar', M. Narayana Rao ${ }^{1}$ \\ ${ }^{1}$ Department of Biotechnology, S. V. University, Tirupati, India \\ ${ }^{2}$ Department of Botany, S. V. University, Tirupati, India \\ Email: "jsrmurthy@yahoo.com
}

Received 1 November 2015; accepted 18 January 2016; published 21 January 2016

Copyright (C) 2016 by authors and Scientific Research Publishing Inc.

This work is licensed under the Creative Commons Attribution International License (CC BY). http://creativecommons.org/licenses/by/4.0/

\section{Abstract}

Rhizobia are vital for nitrogen input, fertility of soil and legume plant growth. Knowledge on rhizobial diversity from arid and semiarid areas is important for dry land agriculture in the context of climatic change and for economic utilization. This study provides morphological, biochemical, stress tolerance and plant growth promoting characteristics of fifteen rhizobial isolates from the nodules of same number of wild legumes and one isolate from cultivated Arachis hypogea from semi-arid region, Tirupati. The bacterial isolates were confirmed as rhizobia based on colony morphology and biochemical tests. Based on the colour change of YMA-BTB medium, eight isolates were identified as slow growers and six were fast growers. The isolates differed in growth pattern, colony morphology, antibiotic resistance at higher concentrations and uniformity in utilization of carbon and nitrogen sources. The isolates are tolerant to $\mathrm{NaCl}$ up to one percent, displayed normal growth at temperatures $28^{\circ} \mathrm{C}-30^{\circ} \mathrm{C}$, at neutral $\mathrm{pH}$ and poor growth at $\mathrm{pH}$ 5and 9 . The isolates varied in the production of EPS and IAA, positive for phosphate solubilization and siderophore formation. This functional diversity displayed by the isolates can be utilised for the legume crop production by cross inoculation.

\section{Keywords}

Wild Legumes, Rhizobia Characterization, Stress Tolerance, Plant Growth Promotion

\footnotetext{
${ }^{*}$ Corresponding author.
}

How to cite this paper: Bhargava, Y., Murthy, J.S.R., Kumar, T.V.R. and Rao, M.N. (2016) Phenotypic, Stress Tolerance and Plant Growth Promoting Characteristics of Rhizobial Isolates from Selected Wild Legumes of Semiarid Region, Tirupati, India. Advances in Microbiology, 6, 1-12. http://dx.doi.org/10.4236/aim.2016.61001 


\section{Introduction}

Symbiotic nitrogen fixation, involving legumes and rhizobia is of considerable economic and ecological significance. Rhizobia are a group of soil bacterial species that infect leguminous plants leading to the formation of special type of organs called nodules, where nitrogen fixation takes place. The nitrogenase enzyme complex of bacterioids i.e. symbiotic form of rhizobia supplies constant source of reduced nitrogen to the legume host and intern, receives the nutrients and energy. This symbiotic process occurs on all continents and accounts for a fourth of the nitrogen fixed annually on earth [1], has become important component of sustainable organic agriculture.

The nitrogen fixing genes are located in Rhizobia and symbiotic establishment and regulation of nitrogenase activity in the nodules depends on the genes of host plant. Host plant genotype compatibility and differences in nitrogen fixation potential of Rhizobial strains often results in variation in symbiotic effectiveness [2]. Establishment of effective symbiosis depends on cross talk between plant host and rhizobia at different stages, starting from the initial recognition of partners, through functional nodule formation and nitrogen reduction [3].

Rhizobium is also a plant growth promoting rhizobacteria (PGPR) exhibit a variety of characteristics responsible for influencing plant growth and performance. As a symbiotic partner in addition to nitrogen supply, Rhizobium also improves nutritional uptake by promoting the growth of plant root system through production of Indole acetic acid (IAA) [4] and as a rhizospheric microbe solubilises phosphorus and various mineral nutrients [5].

Legume crops, which provide dietary proteins, fats and fodder, are preferred in semi-arid agriculture system due to their inherent adaptation to the existing characteristic ecological features and symbiotic nitrogen fixation potential. Climatic changes experienced during the recent years further aggravating ecological problems of arid and semiarid legume cropping areas leading to prolonged dry season, rise in temperature, increase in soil salinity and soil $\mathrm{pH}$ alteration. These typical environmental stresses are problematic for the establishment of effective symbiosis and survival of rhizobia in the soil [6]. Further, the requirement for fertilizer-N is increasing and predicted a need for more than 190.4 million tons by 2015, to supply the world's food. The economic and ecological costs of fertilizer usage will eventually become prohibitive in future due to current technologies employed for fertilizer production and application respectively.

Genetic variability for the environmental stress factors in the commercial inoculants/strains and Rhizobial populations in the agriculture fields most often very limited due to monoculture of legume crops and competition between Rhizobial populations in the soil favours colonization of certain genotypes and co-evolution of symbiotic partners.

Enormous diversity exists in rhizobia due to their wide geographical distribution, different plant hosts and niches they occupy all over the globe [7]. The major challenge in agricultural system, to exploit the enormous potential of symbiotic nitrogen fixation requires the selection and development of efficient inoculant strains compatible to legume host and the target edaphic environment in which their fullest genetic potential of nitrogen fixation expressed. Occurrence of rhizobia in varied ecosystems and their significance for sustainable organic agriculture emphasizes the need for the exploration of non-agricultural areas, indigenous soils and nodulating wild plants to know the rhizobial diversity and their economic utilization. Selection and development of efficient compatible Rhizobial partner for a specific crop is a potential strategy due to their simple genetic system compared to complexity of nodulation genotype of legume plants.

Nodulated wild legumes with their biodiversity and adaptation to arid/semi-arid climatic conditions are vital to the soil fertility and nitrogen cycle [8] and are an important source for elite rhizobial strains. The natural symbiotic rhizobia of these wild legumes exhibit higher tolerance to prevailing adverse conditions like salt stress, elevated temperature and drought, which can be important for increasing productivity of legume crops when cross inoculated.

There were few reports on phenotypic characterization of rhizobia from wild legumes of arid/semiarid regions viz, Rajasthan, India [9], Saudi Arabia [10] and Tunicia [11].

The knowledge on genetic and functional diversity of root-nodule bacteria associated with wild legume flora of arid and semiarid ecosystems of the continents is largely unexplored. This study aimed at evaluating the phenotypic diversity, stress tolerance and plant growth promoting characteristics of rhizobial isolates from wild legumes of semiarid habitat, Tirupati, India.

\section{Materials and Methods}

Isolation of rhizobia: Rhizobial isolates from fifteen nodulating native wild legumes were selected to study 
morphological, biochemical and plant growth promoting characters. Wild legume hosts include Albizia lebbeck, Alysicarpus monilifer, Chamaecrista absus, Cassia tora, Clitoria ternatea, Crotalaria hebecarpa, Desmodium trifolium, Indigofera linnaei, Indigofera mysorensis, Indigofera trifoliata, Millettia pinnata, Mimosa pudica, Rhynchosia minima, Tephrosia purpurea and Tephrosia tinctoria and cultivated Arachis hypogea for comparison. From carefully uprooted roots, soil was removed by gentle washing with tap water, separated from the stem and placed in polythene covers, kept in cool box and brought to the laboratory. By leaving small piece of root above and below the nodules, roots were cut. Root pieces containing nodules were first subjected to surface sterilization with $0.01 \% \mathrm{HgCl}_{2}$ for 30 sec. Traces of $\mathrm{HgCl}_{2}$ were removed by repeated washings with sterile distilled water and then incubated in 70\% ethanol for 3 min and final washings were made with sterile distilled water for 3 times. Randomly selected ten nodules were separated from root part of each species, crushed with sterile glass rod and squeezed for white coloured milky secretion into $0.5 \mathrm{ml}$ of sterile YEM broth. From this suspension loopful of inoculum was streaked onto YEMA medium (Composition per litre: Yeast extract $1 \mathrm{gr}$, Mannitol 10 gr, Dipotassium phosphate 0.5 gr, Magnesium sulphate 0.2 gr, Sodium chloride 0.1 gr, Agar 20 gr, pH 6.8) containing $0.0025 \%$ Congo red [12]. For each isolate three replicates were kept. Fractions from the last washed distilled water were also streaked onto YEMA medium to check the effect of surface sterilization and plates were incubated at $28^{\circ} \mathrm{C}$. Cultures were observed after $3-6$ days and were restreaked onto YEMA medium to obtain single colonies. A single colony reinoculated into YEM broth and maintained on shaker at $200 \mathrm{rpm}$ for the stock culture and use. All cultures were maintained in triplicates and data was recorded after 96 hours of inoculation. The isolates were given codes by taking the first capital letter of genus and first two letters of the species name of the respective original legume host.

Morphological and Biochemical characterization: Isolates were characterized for colony and cell morphology, biochemical characteristics includes (Melanin production test, Ammonia production test, Phosphate solubilisation test, Organic acid production test, Oxidase test, Catalase test, Indole production, Gelatin hydrolysis, Starch hydrolysis) was carriedout following standard methods described by Somasegaran and Hoben [13]. Exopolysaccharides isolation [14] and estimation [15], Siderophore production test [16] were employed. For carbon and nitrogen utilization tests, $10 \%$ sugars or organic acids were prepared; filter sterilized and was added to the basal medium to a final concentration of $1 \%(\mathrm{w} / \mathrm{v})$. Stress tolerance studies including intrinsic antibiotic resistance (IAR), resistance to salinity, $\mathrm{pH}$ and temperature were carriedout by the standard method [17].

Statistical and Cluster analysis: Cluster analysis was performed for rhizobial isolates. Analysis of variance and correlation coefficient was calculated using SPSS version 12 statistical software which was used to estimate the simple matching similarity coefficient (Ssm) of each strain and to generate a similarity matrix [18] computed with Jaccard coefficient. The similarity matrix was used for cluster analysis to construct a phenogram using the unweighted pair group method with averages (UPGMA) [18].

\section{Results and Discussion}

Study site: The study site, S. V. University campus is located in Tirupati $\left(13^{\circ} 62^{\prime} \mathrm{N}\right.$ and $\left.79^{\circ} 40^{\prime} \mathrm{E}\right)$ at foothills of Seshachalam (Tirumala) hill range covering nearly 200 acres (Figure 1) and represent typical semi-arid temperate climate. The mean average annual rainfall is $950 \mathrm{~mm}$ followed by prolonged dry season with mean annual maximum temperature $40^{\circ} \mathrm{C} \pm 2^{\circ} \mathrm{C}$ and a minimum of $20^{\circ} \mathrm{C} \pm 2{ }^{\circ} \mathrm{C}$. Soil is red loamy with poor water holding capacity and organic contents. The site of Arachis hypogea's collection is having similar soil profile but under cultivation for many years.

Morphological characteristics: Bacteria that form nitrogen-fixing nodules in the roots of legumes have different growth rates, morphologies, biosynthetic pathways, catabolic capabilities and habitats depending on host species, edaphic and climatic conditions of habitats. Generally morphological features of the colony i.e, form, elevation and margins vary with rhizobia species/strain [13]. The fifteen isolates from the wild legumes and isolate from cultivated Arachis hypogea displayed variation in colony morphological features including, form, elevation, margin and opacity (Table 1 ).

Morphology of the colony formed by Cte, Tpu, and Tti isolates was irregular and the colonies of remaining isolates were regular. The colony elevation was flat in Che, Itr, Imy and Tti, raised in Cab, Cto, Cte, Ili, Rmi and $\mathrm{Tpu}$, and convex in the remaining isolates. Margin of the colony was lobate in Cte, Che, Rmi and Tpu and in the remaining 11 isolates it was entire. The circular and irregular colonies are in agreement with characteristic colony forms of rhizobia [13]. The colonies were creamy coloured and mucose. Eight isolates are categorized as slow growers and remaining six isolates as fast growers based on the colour change of YMA-BTB medium to 


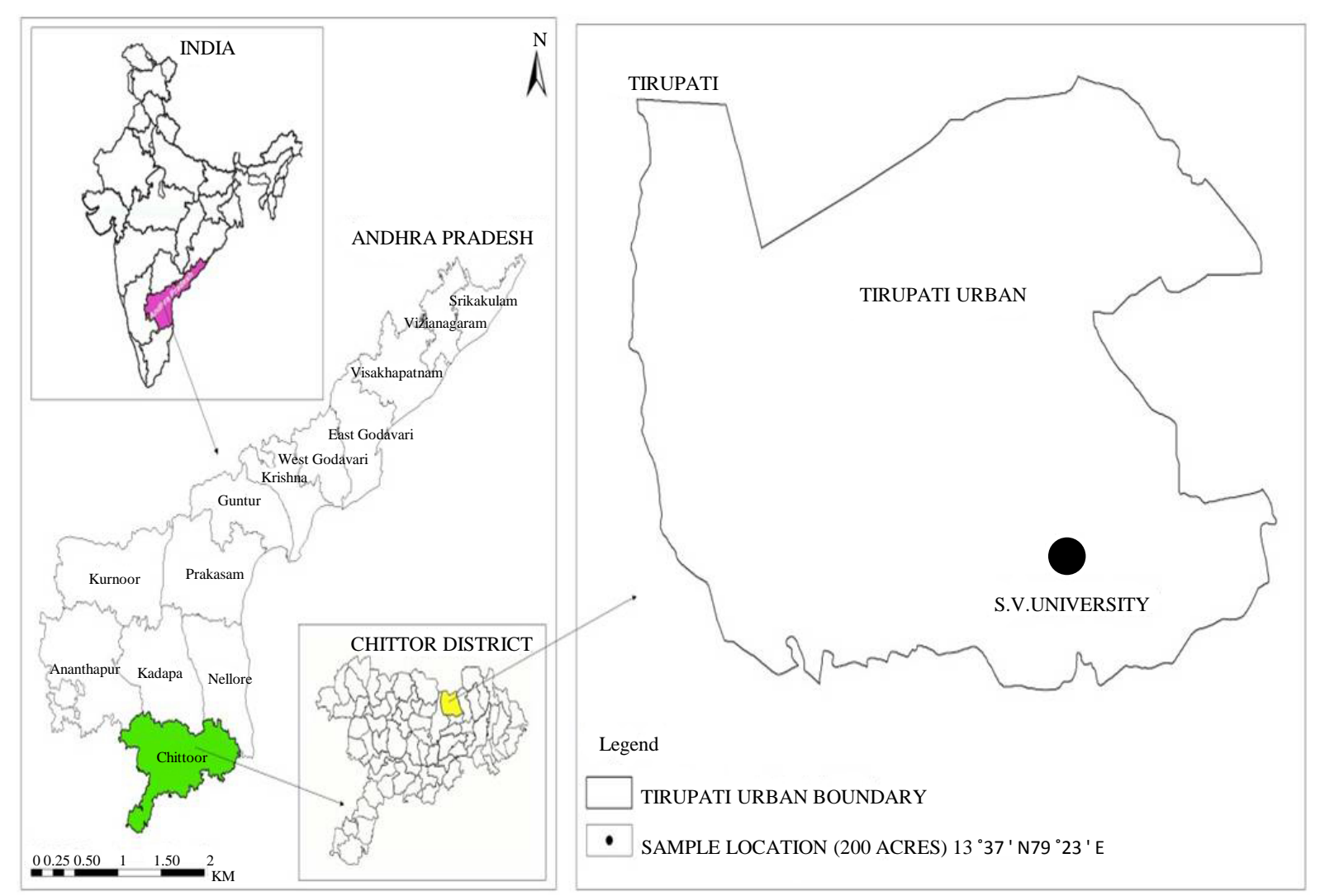

Figure 1. Study site.

Table 1. Colony morphology and cultural characteristics of the rhizobial isolates.

\begin{tabular}{|c|c|c|c|c|c|}
\hline \multirow{2}{*}{ S. No. } & \multirow{2}{*}{ Isolate } & \multicolumn{4}{|c|}{ Cultural characteristics } \\
\hline & & Form & Elevation & Margin & Growth rate \\
\hline 1 & Albizia lebbeck (Ale) & Circular & Convex & Entire & Slow \\
\hline 2 & Alysicarpus monilifer (Amo) & Circular & Convex & Entire & Fast \\
\hline 3 & Arachis hypogea (Ahy) & Circular & Convex & Entire & Fast \\
\hline 4 & Chamaecrista absus (Cab) & Circular & Raised & Entire & Slow \\
\hline 5 & Cassia tora (Cto) & Circular & Raised & Entire & Slow \\
\hline 6 & Clitoria ternatea (Cte) & Irregular & Raised & Lobate & Fast \\
\hline 7 & Crotalaria hebecarpa (Che) & Circular & Flat & Lobate & Fast \\
\hline 8 & Desmodium trifolium (Dtr) & Circular & Convex & Entire & Fast \\
\hline 9 & Indigofera linnaei (Ili) & Circular & Raised & Entire & Slow \\
\hline 10 & Indigofera mysorensis (Imy) & Circular & Flat & Entire & Slow \\
\hline 11 & Indigofera trifoliata (Itr) & Circular & Flat & Entire & Slow \\
\hline 12 & Millettia pinnata (Mpi) & Circular & Convex & Entire & Fast \\
\hline 13 & Mimosa pudica (Mpu) & Circular & Convex & Entire & Fast \\
\hline 14 & Rhynchosia minima (Rmi) & Circular & Raised & Lobate & Fast \\
\hline 15 & Tephrosia purpurea $($ Трu) & Irregular & Raised & Lobate & Slow \\
\hline 16 & Tephrosia tinctoria (Tti) & Irregular & Flat & Entire & Slow \\
\hline
\end{tabular}

Note: All isolates exhibit characteristic colony colour creamy on YEMA, white on YEMA with Congo red, blue and yellow on YEMA with BTB. Mucose in appearance, aerobic and non-spore forming in nature. 
blue and yellow (Table 1) depending on acid and alkaline production respectively as reported earlier by Saeki et al. [19].

When the light transmittency of the colony is considered, it is transparent in Cab, Cto, Dtr, Imy, Rmi, Tpu and Tti, and opaque in the remaining isolates. All isolates were aerobic, rod shaped, gram negative and motile. The discriminative power of colony morphology characters in revealing genetic diversity among the isolates was realised when the combination of four characters (form, elevation, margin and opacity) were considered. The isolates formed into 11 groups of which 9 were loners; one group represented by 5 isolates and another with 2 isolates.

Biochemical characters: The isolates are positive to Ammonia, Catalase, Indole, Melanin, Oxidase and $\mathrm{H}_{2} \mathrm{~S}$ production tests. Further, isolates are also positive to MR-VP test, Starch hydrolysis, and negative to gelatin hydrolysis test (Table 2).

Phenotypic characteristics: Several techniques for characterization, identification and assessment of metabolic diversity of strains have been developed, such as Carbon, Nitrogen sources utilization and Intrinsic Antibiotic Resistance pattern. Of 11 sugars tested all the isolates were able to utilise fructose, galactose, glucose, mannose, sucrose, starch, succinate, rhamnose, malate, citrate and they fail to utilise dulcitol as carbon source (Table 3). In the case of nitrogen sources utilization all the isolates were able to utilise glutamate, ammonium chloride, aspartate, tryptophan, glycine and unable to utilise potassium nitrate and casein hydrolysate (Table 3). Similar response of isolates to carbon and nitrogen utilization may be due to lack of variation in the genes operating in these pathways. The results of biochemical tests, carbon and nitrogen sources utilization pattern of isolates compared with Bergey's Manual of Determinative Bacteriology [20] and were confirmed as Rhizobia.

\subsection{Intrinsic Antibiotic Resistance (IAR)}

Different rhizobial strains show different degrees of susceptibility to antibiotics due to genetic variation in target genes and resistance genes acquired through horizontal gene transfer. Many researchers emphasized the significance of intrinsic resistance as a phenotypic character for discrimination and identification rhizobial strains [21].

Table 2. Biochemical characteristics of rhizobial isolates.

\begin{tabular}{|c|c|c|c|c|c|c|c|c|c|c|c|}
\hline \multirow[b]{2}{*}{ S. No. } & \multirow[b]{2}{*}{ Isolate } & \multicolumn{10}{|c|}{ Biochemical characterization } \\
\hline & & 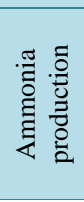 & 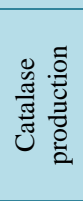 & 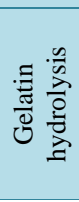 & 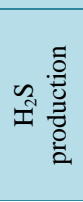 & 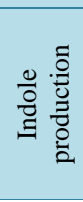 & 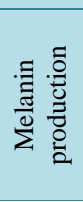 & 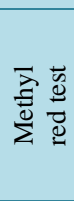 & 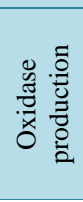 & 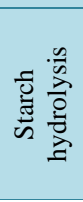 & 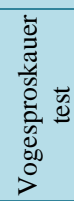 \\
\hline 1 & Ale & + & + & - & + & + & + & + & + & + & + \\
\hline 2 & Amo & + & + & - & + & + & + & + & + & + & + \\
\hline 3 & Ahy & + & + & - & + & + & + & + & + & + & + \\
\hline 4 & Cab & + & + & - & + & + & + & + & + & + & + \\
\hline 5 & Cto & + & + & - & + & + & + & + & + & + & + \\
\hline 6 & Cte & + & + & - & + & + & + & + & + & + & + \\
\hline 7 & Che & + & + & - & + & + & + & + & + & + & + \\
\hline 8 & Dtr & + & + & - & + & + & + & + & + & + & + \\
\hline 9 & Ili & + & + & - & + & + & + & + & + & + & + \\
\hline 10 & Imy & + & + & - & + & + & + & + & + & + & + \\
\hline 11 & Itr & + & + & - & + & + & + & + & + & + & + \\
\hline 12 & Mpi & + & + & - & + & + & + & + & + & + & + \\
\hline 13 & $\mathrm{Mpu}$ & + & + & - & + & + & + & + & + & + & + \\
\hline 14 & Rmi & + & + & - & + & + & + & + & + & + & + \\
\hline 15 & Tpu & + & + & - & + & + & + & + & + & + & + \\
\hline 16 & Tti & + & + & - & + & + & + & + & + & + & + \\
\hline
\end{tabular}

+ Indicates positive-indicates negative. 
Table 3. Carbon and nitrogen sources utilization ability of the rhizobial isolates.

\begin{tabular}{|c|c|c|c|c|c|c|c|c|c|c|c|c|c|c|c|c|}
\hline Characteristic & Ale & Amo & Ahy & Cab & Cto & Cte & Che & Tti & Dtr & Ili & Imy & Tpu & Itr & Mpi & Mpu & Rmi \\
\hline \multicolumn{17}{|l|}{$\begin{array}{l}\text { Carbon } \\
\text { sources }\end{array}$} \\
\hline Citrate & + & + & + & + & + & + & + & + & + & + & + & + & + & + & + & + \\
\hline Dulcitol & - & - & - & - & - & - & - & - & - & - & - & - & - & - & - & - \\
\hline Fructose & + & + & + & + & + & + & + & + & + & + & + & + & + & + & + & + \\
\hline Galactose & + & + & + & + & + & + & + & + & + & + & + & + & + & + & + & + \\
\hline Glucose & + & + & + & + & + & + & + & + & + & + & + & + & + & + & + & + \\
\hline Malate & + & + & + & + & + & + & + & + & + & + & + & + & + & + & + & + \\
\hline Mannitol & + & + & + & + & + & + & + & + & + & + & + & + & + & + & + & + \\
\hline Rhamnose & + & + & + & + & + & + & + & + & + & + & + & + & + & + & + & + \\
\hline Starch & + & + & + & + & + & + & + & + & + & + & + & + & + & + & + & + \\
\hline Succinate & + & + & + & + & + & + & + & + & + & + & + & + & + & + & + & + \\
\hline Sucrose & + & + & + & + & + & + & + & + & + & + & + & + & + & + & + & + \\
\hline \multicolumn{17}{|l|}{$\begin{array}{c}\text { Nitrogen } \\
\text { sources }\end{array}$} \\
\hline $\begin{array}{l}\text { Ammonium } \\
\text { chloride }\end{array}$ & + & + & + & + & + & + & + & + & + & + & + & + & + & + & + & + \\
\hline Asparagine & + & + & + & + & + & + & + & + & + & + & + & + & + & + & + & + \\
\hline $\begin{array}{c}\text { Casein } \\
\text { hydrolysate }\end{array}$ & - & - & - & - & - & - & - & - & - & - & - & - & - & - & - & - \\
\hline Glycine & + & + & + & + & + & + & + & + & + & + & + & + & + & + & + & + \\
\hline Glutamine & + & + & + & + & + & + & + & + & + & + & + & + & + & + & + & + \\
\hline $\begin{array}{l}\text { Potassium } \\
\text { nitrate }\end{array}$ & - & - & - & - & - & - & - & - & - & - & - & - & - & - & - & - \\
\hline Tryptophan & + & + & + & + & + & + & + & + & + & + & + & + & + & + & + & + \\
\hline
\end{tabular}

+ Indicates positive-indicates negative.

A total of 9 known antibiotics were employed to know the resistance/susceptibility of the isolates (Table 4). All the isolates showed resistance to 9 antibiotics at their respective minimum concentrations tested. The isolates Cab and Tti showed resistance to all 9 antibiotics at all concentrations. The isolate Ale showed resistance to six antibiotics at all the concentrations tested, whereas, it was sensitive to higher concentrations of Carbenicillin $(500 \mu \mathrm{g} / \mathrm{ml})$, Streptomycin $(100 \mu \mathrm{g} / \mathrm{ml})$ and Vanomycin $(100 \mu \mathrm{g} / \mathrm{ml})$. Regarding resistance to Nalidixicacid (100 $\mu \mathrm{g} / \mathrm{ml})$ and Trimethoprim $(100 \mu \mathrm{g} / \mathrm{ml})$ the isolates are in agreement with the report of Sharma et al. [22]. All the present isolates are resistant to even higher concentration of Chloramphenicol (300 $\mu \mathrm{g} / \mathrm{ml})$ however; Sharma et al. [22] and Shetta et al. [10] reported sensitivity of isolates even to $100 \mu \mathrm{g} / \mathrm{ml}$ and $200 \mu \mathrm{g} / \mathrm{ml}$ respectively. The isolates are resistant to $300 \mu \mathrm{g} / \mathrm{ml}$ Rifampicin as against the report of Shetta et al. [10] at $200 \mu \mathrm{g} / \mathrm{ml}$. Fast and slow growing rhizobia display variation in resistance to antibiotics. Higher IAR pattern in slow growing Bradyrhizobia than fast growing rhizobia was also reported by Padmanabham et al. [23]. No clear distinction between fast and slow growing isolates in their intrinsic antibiotic resistance to the nine antibiotics tested could be made and these results are in agreement with Sharma et al. [22]. Some of the fast growing isolates (Cte, Che, Dtr) and slow growing isolates (Cto, Tpu) are resistant to moderate concentrations of Carbenicillin ( $350 \mu \mathrm{g} / \mathrm{ml})$ and Vanomycin $(75 \mu \mathrm{g} / \mathrm{ml})$ which interfere in cell wall synthesis. Considering different modes of action of antibiotics employed and resistance displayed some isolates at higher concentrations indicates variation in determinants of permeability to antibiotics. However, the two isolates Cab and Tti showing resistance to all antibiotics were found to be slow growers and producing high amount of EPS which may be preventing uptake of the antibiotic into the cells.

Salt tolerance: One of the major problems in semi-arid regions is increase in the salinity levels of the soil. Application of salinity tolerant rhizobia in legume cropping area helps in the formation of effective nodules and efficient nitrogen fixation. Symbiotic effectiveness depends on the specific combination of compatible legume and rhizobium under the saline conditions [24]. The response of 15 isolates was similar to the $\mathrm{NaCl}$ percentage ranging from $0.5 \%-3.5 \%$ (Table 5). Nearly normal growth was observed in $0.5 \%$ and $1 \% \mathrm{NaCl}$. The growth 
Table 4. Intrinsic antibiotic resistance (IAR) of the isolates.

\begin{tabular}{|c|c|c|c|c|c|c|c|c|c|c|c|c|c|c|c|c|}
\hline $\begin{array}{c}\text { Antibiotic } \\
\text { (Concentration } \\
\text { in } \mu \mathrm{g} \cdot \mathrm{ml}^{-1} \text { ) }\end{array}$ & Ale & Amo & Ahy & $\mathrm{Cab}$ & Cto & Cte & Che & Dtr & Ili & Imy & Itr & Mpi & $\mathrm{Mpu}$ & Rmi & Tpu & $\mathrm{Tti}$ \\
\hline \multicolumn{17}{|l|}{ Carbenicillin } \\
\hline 250 & + & + & + & + & + & + & + & + & + & + & + & + & + & + & + & + \\
\hline 350 & + & - & - & + & + & + & + & + & - & - & - & - & - & - & + & + \\
\hline 500 & - & - & - & + & - & - & - & - & - & - & - & - & - & - & - & + \\
\hline \multicolumn{17}{|l|}{ Chloramphenicol } \\
\hline 300 & + & + & + & + & + & + & + & + & + & + & + & + & + & + & + & + \\
\hline 500 & + & - & - & + & - & - & - & - & - & - & - & - & - & - & - & + \\
\hline \multicolumn{17}{|l|}{ Erythromycin } \\
\hline 150 & + & + & + & + & + & + & + & + & + & + & + & + & + & + & + & + \\
\hline 250 & + & - & - & + & - & - & - & - & - & - & - & - & - & - & - & + \\
\hline \multicolumn{17}{|l|}{ Nalidixicacid } \\
\hline 50 & + & + & + & + & + & + & + & + & + & + & + & + & + & + & + & + \\
\hline 75 & + & - & - & + & - & - & - & - & - & - & - & - & - & - & - & + \\
\hline \multicolumn{17}{|l|}{ Rifampicin } \\
\hline 300 & + & + & + & + & + & + & + & + & + & + & + & + & + & + & + & + \\
\hline 500 & + & - & - & + & - & - & - & - & - & - & - & - & - & - & - & + \\
\hline \multicolumn{17}{|l|}{ Streptomycin } \\
\hline 75 & + & + & + & + & + & + & + & + & + & + & + & + & + & + & + & + \\
\hline 100 & - & - & - & + & - & - & - & - & - & - & - & - & - & - & - & + \\
\hline \multicolumn{17}{|l|}{ Tetracycline } \\
\hline 50 & + & + & + & + & + & + & + & + & + & + & + & + & + & + & + & + \\
\hline 100 & + & - & - & + & - & - & - & - & - & - & - & - & - & - & - & + \\
\hline \multicolumn{17}{|l|}{ Trimethoprim } \\
\hline 50 & + & + & + & + & + & + & + & + & + & + & + & + & + & + & + & + \\
\hline 75 & + & - & - & + & - & - & - & - & - & - & - & - & - & - & - & + \\
\hline \multicolumn{17}{|l|}{ Vanomycin } \\
\hline 50 & + & + & + & + & + & + & + & + & + & + & + & + & + & + & + & + \\
\hline 75 & + & - & - & + & + & + & + & + & - & - & - & - & - & - & + & + \\
\hline 100 & - & - & - & + & - & - & - & - & - & - & - & - & - & - & - & + \\
\hline
\end{tabular}

+ Indicates positive-indicates negative.

was decreased thereafter with increase in concentration upto 3.5\% and no growth was observed in $4.5 \%$. Decrease in growth of rhizobial isolates with increased salt concentration was also reported by Ali et al. [9] and Thrall et al. [25], this may be due to toxicity and also osmotic stress imposed by salinity [25] [26]. The isolates from woody legumes of Saudi Arabia showed nearly normal growth up 3\% $\mathrm{NaCl}$ [10], rhizobia from Lotus spp. of arid soils of Tunisia tolerated $\mathrm{NaCl}$ concentration up to $4.8 \%$ [11] and isolates from native wild legumes of Aravalli region of Rajasthan showed variation in $\mathrm{NaCl}$ tolerance from $2 \%$ - 6\% [27]. The difference in the salinity tolerance levels may be due to the genetic diversity and physiological adaptations. Similar response of 15 Rhizobial isolates of wild legumes and cultivated species to the $\mathrm{NaCl}$ concentrations may be due to the physiological adaptation of rhizobia to the native soil as these were isolated from the same geographical region.

Temperature tolerance: The growth and survival of rhizobia in soils are adversely affected by high soil temperatures [28]. Hence, selection of temperature tolerant strains helps in their survival in soil and establishment of effective symbiosis. Temperature stress alters the permeability of the membrane and causes denaturation of certain enzymes/proteins leading to the death/poor growth of the rhizobia. All the isolates showed maximum 
Table 5. Growth pattern of the rhizobial isolates under temperature, $\mathrm{pH}$ and salinity stress.

\begin{tabular}{|c|c|c|c|c|c|c|c|c|c|c|c|c|c|c|c|c|}
\hline Characteristic & Ale & Amo & Ahy & Cab & Cto & Cte & Che & Dtr & Ili & Imy & Itr & Mpi & $\mathrm{Mpu}$ & Rmi & Tpu & Tti \\
\hline \multicolumn{17}{|l|}{$\begin{array}{l}\text { Growth at } \\
\text { Temperature } \\
\left({ }^{\circ} \mathrm{C}\right)\end{array}$} \\
\hline 28 & ++ & ++ & ++ & ++ & ++ & ++ & ++ & ++ & ++ & ++ & ++ & ++ & ++ & ++ & ++ & ++ \\
\hline 33 & + & + & + & + & + & + & + & + & + & + & + & + & + & + & + & + \\
\hline 38 & + & + & + & + & + & + & + & + & + & + & + & + & + & + & + & + \\
\hline 43 & + & + & + & + & + & + & + & + & + & + & + & + & + & + & + & + \\
\hline 48 & - & - & - & - & - & - & - & - & - & - & - & - & - & - & - & - \\
\hline \multicolumn{17}{|l|}{ Growth at pH } \\
\hline 5 & - & - & - & - & - & - & - & - & - & - & - & - & - & - & - & - \\
\hline 6 & + & + & + & + & + & + & + & + & + & + & + & + & + & + & + & + \\
\hline 7 & ++ & ++ & ++ & ++ & ++ & ++ & ++ & ++ & ++ & ++ & ++ & ++ & ++ & ++ & ++ & ++ \\
\hline 8 & + & + & + & + & + & + & + & + & + & + & + & + & + & + & + & + \\
\hline 9 & - & - & - & - & - & - & - & - & - & - & - & - & - & - & - & - \\
\hline \multicolumn{17}{|l|}{$\begin{array}{c}\text { Growth at Salinity } \\
\qquad(\%)\end{array}$} \\
\hline 0.5 & ++ & ++ & ++ & ++ & ++ & ++ & ++ & ++ & ++ & ++ & ++ & ++ & ++ & ++ & ++ & ++ \\
\hline 1.5 & ++ & ++ & ++ & & & & & & & & & & & & & \\
\hline 2.5 & + & + & + & + & + & + & + & + & + & + & + & + & + & + & + & + \\
\hline 3.5 & + & + & + & + & + & + & + & + & + & + & + & + & + & + & + & + \\
\hline 4.5 & - & - & - & - & - & - & - & - & - & - & - & - & - & - & - & - \\
\hline
\end{tabular}

+ Indicates positive-indicates negative.

growth at $28^{\circ} \mathrm{C}$, moderate growth at $33^{\circ} \mathrm{C}$ and $38^{\circ} \mathrm{C}$, poor growth at $23^{\circ} \mathrm{C}$ and $43^{\circ} \mathrm{C}$ (Table 5). The growth was completely inhibited at $48^{\circ} \mathrm{C}$. The optimum temperature range $\left(25^{\circ} \mathrm{C}-30^{\circ} \mathrm{C}\right)$ for the growth and response of the present isolates to the elevated temperatures is similar to that of rhizobial isolates from wild legumes of Rajasthan as reported by Ali et al. [9], Harwani [29] and Saudi Arabian tree legumes by Shetta et al. [10].

PH tolerance: Soil $\mathrm{pH}$ influences the growth and survival of rhizobia through alteration in the permeability of the membrane and uptake of nutrients. Neutral $\mathrm{pH}$ allows the uptake of appropriate amount of nutrients and results in optimum growth of rhizobia. At neutral $\mathrm{pH}$ all the isolates showed maximum growth, the growth was decreased with increase in acidity or alkalinity (Table 5). Growth was poor at pH 5 and 9. Almost similar results were reported by Ali et al. [9] and Harwani [29] of the isolates from the legumes of Rajasthan. The optimum pH 6.5 - 7.0 for the growth of the isolates is also in agreement with the reports of Rodrigues et al. [30] and Shetta et al. [10]. The isolates from two native wild legumes from Aravalli ranges of Rajasthan, India able to grow at $\mathrm{pH}$ ranged from 3 - 11 [27]. Sino and Mesorhizobium sp. isolated from Lotus spp. in arid soils of Tunisia found to grow at $\mathrm{pH}$ between 5.5 and 9 [11]. This may be due variation in membrane properties.

\subsection{Plant Growth Promoting Characters}

Rhizobia in addition to the nitrogen supply, they promote growth of the plant as a symbiotic partner and soil microbe in a number of ways. Plant growth could be induced by rhizobia through some of their growth stimulating mechanisms such as mobilization of nutrient, enhancement in stress resistance, solubilization of phosphates, production of phytohormones and siderophores [31]. Symbiotically produced IAA alone or along with other plant hormones involved in several stages of establishment of symbiotic relationship and also transported to the plant for its use. Rhizobial induced local accumulation of auxins stimulates the formation of nodule primordia [32] and also necessary for growth and maintenance of root nodules. Ghosh et al. [33] suggested that IAA content produced by the bacterioids in the nodule and supplied to the host plant is the second line of symbiosis apart from nitrogen fixation.

Rhizobial isolates varied in IAA production, a maximum of, $27 \mu \mathrm{g} / \mathrm{ml}$ and a minimum of $6 \mu \mathrm{g} / \mathrm{ml}$ produced by Cte and Ale isolates respectively (Table 6). Majority the isolates produced $20 \pm 2 \mu \mathrm{g} / \mathrm{ml}$ of IAA, 7 isolates 
Table 6. Plant growth promoting characteristics of the isolates.

\begin{tabular}{|c|c|c|c|c|c|}
\hline S. No. & Isolate & Siderophore production test & Phosphate solubilization test & IAA $(\mu \mathrm{g} / \mathrm{ml})$ & EPS $(\mu \mathrm{g} / \mathrm{ml})$ \\
\hline 1 & Ale & + & + & $06^{\mathrm{a}} \pm 1.67$ & $63^{\mathrm{a}} \pm 5.59$ \\
\hline 2 & Amo & + & + & $15^{\mathrm{b}} \pm 1.16$ & $38^{\mathrm{b}} \pm 3.34$ \\
\hline 3 & Ahy & + & + & $19^{c} \pm 0.55$ & $43^{\mathrm{b}, \mathrm{d}} \pm 3.74$ \\
\hline 4 & Cab & + & + & $12^{\mathrm{b}} \pm 1.94$ & $81^{c} \pm 3.08$ \\
\hline 5 & Cto & + & + & $13^{\mathrm{b}} \pm 1.55$ & $55^{\mathrm{a}} \pm 4.64$ \\
\hline 6 & Cte & + & + & $27^{\mathrm{d}} \pm 1.41$ & $59^{\mathrm{a}} \pm 3.88$ \\
\hline 7 & Che & + & + & $18^{\mathrm{c}} \pm 1.41$ & $56^{\mathrm{a}} \pm 5.98$ \\
\hline 8 & Dtr & + & + & $20^{c} \pm 1.47$ & $58^{\mathrm{a}} \pm 3.45$ \\
\hline 9 & Ili & + & + & $18^{\mathrm{c}} \pm 0.89$ & $44^{\mathrm{b}, \mathrm{d}} \pm 3.94$ \\
\hline 10 & Imy & + & + & $21^{\mathrm{e}} \pm 0.98$ & $42^{\mathrm{b}, \mathrm{d}} \pm 5.06$ \\
\hline 11 & Itr & + & + & $17^{\mathrm{e}} \pm 0.76$ & $48^{\mathrm{d}} \pm 3.45$ \\
\hline 12 & Mpi & + & + & $22^{\mathrm{e}} \pm 1.16$ & $34^{\mathrm{b}} \pm 3.35$ \\
\hline 13 & Mpu & + & + & $23^{\mathrm{e}} \pm 1.09$ & $23^{\mathrm{e}} \pm 4.18$ \\
\hline 14 & Rmi & + & + & $13^{\mathrm{b}} \pm 0.81$ & $27^{\mathrm{e}} \pm 3.03$ \\
\hline 15 & Tpu & + & + & $09^{\mathrm{f}} \pm 0.83$ & $68^{\mathrm{a}} \pm 3.41$ \\
\hline 16 & Tti & + & + & $08^{\mathrm{a}, \mathrm{f}} \pm 0.75$ & $91^{\mathrm{f}} \pm 3.74$ \\
\hline
\end{tabular}

Means are value of six replications; Means followed by the same letter in a column are not significantly different but by different letters are significantly different $(\mathrm{p}=0.05)$. + indicates positive.

produced more than $10 \mu \mathrm{g} / \mathrm{ml}$ of IAA and 5 strains produced more than $20 \mu \mathrm{g} / \mathrm{ml}$. The range of IAA produced by these isolates is in agreement with soybean isolates [34]. Most of the isolates can be considered as high IAA producing rhizobia, according to Hynes et al. [35] report, where 5 - $10 \mu \mathrm{g} / \mathrm{ml}$ of IAA production is more common among rhizobia,

Variation in the production of IAA by different rhizobial species/strains and influence of cultural conditions on the amount of IAA produced reported by many workers [36] [37]. Variation in IAA production by different isolates could be due to variation in utilization of L-Tryptophan. This enhanced IAA production capability not only helps in the establishment of effective symbiosis but also promotes the plant growth.

Polysaccharide production is a marked characteristic of rhizobia and involved in infection process and nodule formation. Polysaccharides also protect rhizobia in the soil against deleterious biotic and abiotic stress factors [38] and also restrict the oxygen diffusion through the nodular cells to protect the oxygen sensitive nitrogenase in the nodules. The amount of EPS produced by the isolates in the culture varied from $23-91 \mu \mathrm{g} / \mathrm{ml}$ which is a fourfold variation (Table 5). A maximum of $91 \mu \mathrm{g} / \mathrm{ml}$ observed in Tti followed by $81 \mu \mathrm{g} / \mathrm{ml}$ in Cab and a minimum of $23 \mu \mathrm{g} / \mathrm{ml}$ in Mpu. High amount of EPS production is mostly by the fast growing strains and lowest amount produced by the slow growing strains. Intermediate values obtained with few fast and slow growing strains in the present study. The same was also reported [38] from studies on indigenous rhizobia in Caatinga. Variation in the production of EPS by the isolates was also reported by Rathore et al. [27]. Rhizobia, in addition to N2-fixing activity also improve legumes phosphate nutrition by mobilizing from inorganic and organic sources [39]. All the isolates in the present investigation solubilized Tri Calcium Phosphate (TCP). This solubilisation of phosphate is due to the excretion of organic acids by the rhizobial isolates, which was significantly correlated with a drop in the $\mathrm{pH}$ of the culture filtrates. All the isolates able to form siderophores which acts as iron source for the plant under iron depleted conditions [31].

Cluster analysis: Cluster analysis including colony morphology, biochemical characteristics, IAA and EPS production features, the 16 isolates resolved into five clusters at a distance of 0.205 (Figure 2). Three clusters formed by groups of 4, 5 and 3 isolates, two clusters formed by two isolate each. The three isolates from the Indigofera genus were included in the first cluster along with isolate from Albizia lebbeck. The two isolates from Chamaecrista absus and Cassia tora are included in the third cluster along with Rmi. The two isolates from Tephrosia species i.e., Tephrosia purpurea and Tephrosia tinctoria formed a separate fifth cluster. Absence of $100 \%$ similarity between any two isolates and their grouping into clusters revealing variation even among iso- 

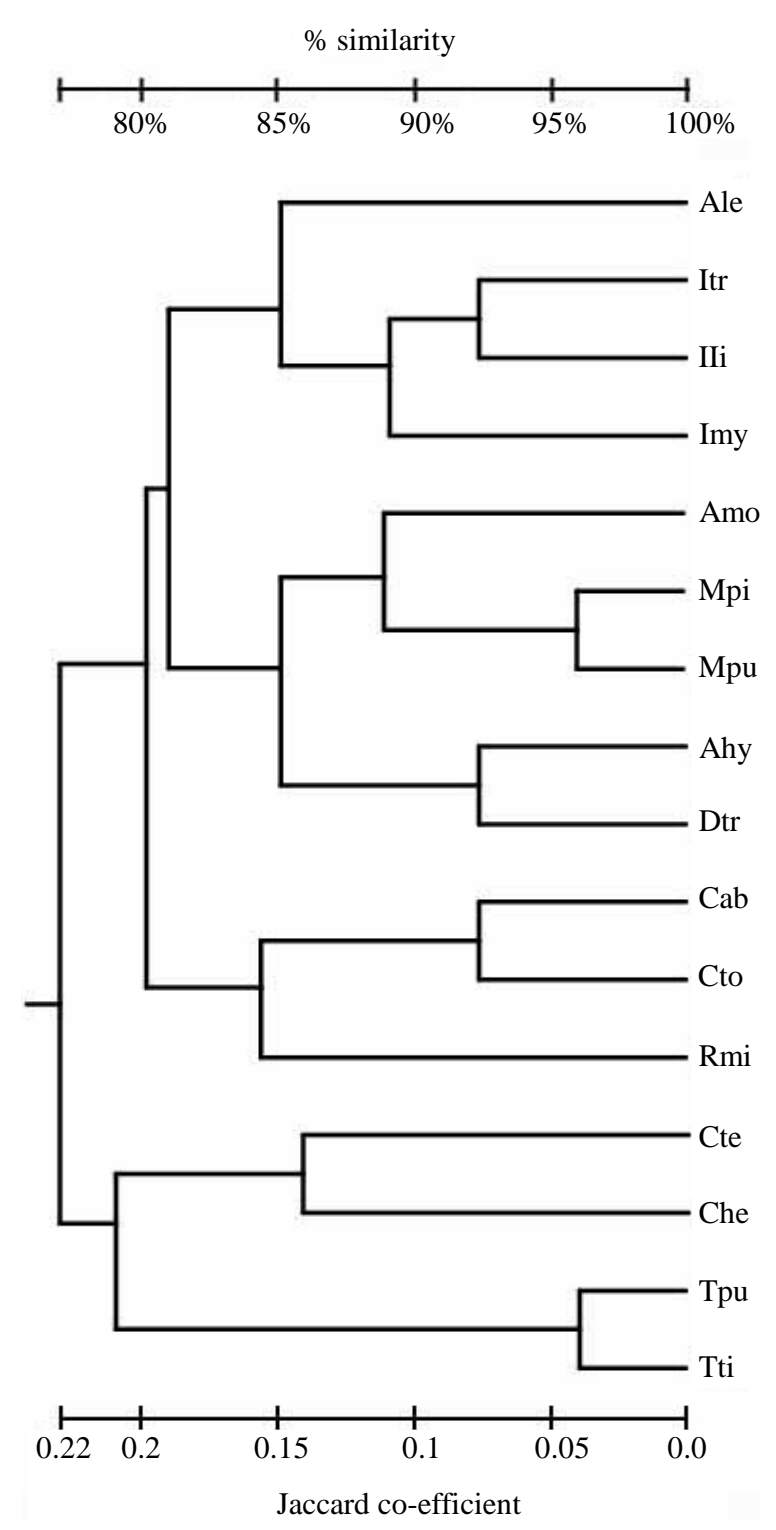

Figure 2. UPGMA dendrogram showing the clustering of isolates based on colony and biochemical characteristics.

lates from the legume hosts belonged to same genus.

\section{Conclusion}

The rhizobial isolates showed variation in colony morphological features including form, elevation, margin and opacity, and Intrinsic Antibiotic Resistance. The isolates tolerated moderate level of salinity, temperature and showed optimum growth at neutral pH. Majority of rhizobia are significantly high IAA producers, and all isolates displayed other plant growth promoting EPS, siderophore production and phosphate solubilisation. Molecular characterization for the species/strain identification is in progress. Functional diversity of isolates can be utilised for the improvement of nitrogen fixation in legume crops through cross inoculation.

\section{References}

[1] Boivin, C.M., Giraud, E., Perret, X. and Batut, J. (2009) Establishing Nitrogen-Fixing Symbiosis with Legumes: How Many Rhizobium Recipes? Trends in Microbiology, 17, 458-466. http://dx.doi.org/10.1016/j.tim.2009.07.004 
[2] Brockwell, J. and Katznelson, J. (1976) Symbiotic Characteristics of Rhizobium trifolii from Israel in Association with 10 Species of Trifolium. Australian Journal of Agricultural Research, 27, 799-810.

http://dx.doi.org/10.1071/AR9760799

[3] Long, S.R., Ehrhardt, D.W. (1989) New Route to a Sticky Subject. Nature, 338, 545-546. http://dx.doi.org/10.1038/338545a0

[4] Etesami, H., Hossein, A.A. and Abolfazl, A.A. (2009) Evaluation of Plant Growth Hormones Production (IAA) Ability by Iranian Soils Rhizobial Strains and Effects of Superior Strains Application on Wheat Growth Indexes. World Applied Sciences Journal, 6, 1576-1584.

[5] Khan, M.S., Zaidi, A. and Wani, P.A. (2006) Role of Phosphate-Solubilizing Microorganisms in Sustainable Agriculture-A Review. Agronomy for Sustainable Development, 27, 29-43. http://dx.doi.org/10.1051/agro:2006011

[6] Zahran, H.H. (1999) Rhizobium-Legume Symbiosis and Nitrogen Fixation under Severe Conditions and in Aride Climate. Microbiology and Molecular Biology Reviews, 63, 968-989.

[7] Martínez-Romero, E. and Caballero-Mellado, J. (1996) Rhizobium Phylogenies and Bacterial Genetic Diversity. Critical Reviews in Plant Sciences, 15, 113-140. http://dx.doi.org/10.1080/07352689.1996.10393183

[8] Sprent, J.I. and Gehlot, H.S. (2011) Nodulated Legumes in Arid And Semi-Arid Environments: Are They Important? Plant Ecology \& Diversity, 3, 211-219. http://dx.doi.org/10.1080/17550874.2010.538740

[9] Ali, S.F., Rawat, L.S., Meghvansi, M.K. and Mahna, S.K. (2009) Selection of Stress-Tolerant Rhizobial Isolates of Wild Legumes Growing in Dry Regions of Rajasthan, India. ARPN Journal of Agricultural and Biological Science, 4, 13-18.

[10] Shetta, N.D., Al-Shaharani, T.S. and Abdel-Aal, M. (2011) Identification and Characterization of Rhizobium Associated with Woody Legume Trees Grown under Saudi Arabia Condition. American-Eurasian Journal of Agricultural \& Environmental Sciences, 10, 410-418.

[11] Rejii, M., Mahdhi, M., Núñez, J.A.D. and Mars, M. (2014) The Phenotypic, Phylogenetic and Symbiotic Characterization of Rhizobia Nodulating Lotus sp. in Tunisian Arid Soils. Annals of Microbiology, 64, 355-362. http://dx.doi.org/10.1007/s13213-013-0670-5

[12] Vincent, J.M. (1970) A Manual for Practical Study of Root Nodule Bacteria. Blackwell Scientific Publishers, Oxford, 164.

[13] Somasegaran, P. and Hoben, H.J. (1985) Methods in Legume-Rhizobium Technology. NifTAL Project and MIRCEN. Department of Agronomy, 2nd Soil Science Hawaii Institute Tropical Agriculture Human Research, University of Hawaii at Manoa, Honolulu, 1-52.

[14] Mukherjee, S., Ghosh, S., Sadhu, S., Ghosh, P. and Maiti, T.K. (2010) Extracellular Polysaccharides Production by a Rhizobium sp. Isolated from Legume Herb Crotalaria Saltiana Andr. Indian Journal of Biotechnology, 10, 340-345.

[15] Dubois, M., Gilles, K.A., Hamilton, J.K., Rebers, R.A. and Smith, F. (1956) Colorimetric Method for Determination of Sugar and Related Substances. Analytical Chemistry, 28, 350-356. http://dx.doi.org/10.1021/ac60111a017

[16] Milagres, A.M.F., Napoleao, D. and Machuca, A. (1999) Detection of Siderophore Production from Several Fungi and Bacteria by Modification of Chrome Azurol S (CAS) Agar Plate Assay. Journal of Microbiological Methods, 37, 1-6. http://dx.doi.org/10.1016/S0167-7012(99)00028-7

[17] Surange, S., Wollum, A.G., Kumar, N. and Nautiyal, C.S. (1997) Characterization of Rhizobium from Root Nodules of Leguminous Trees Growing in Alkaline Soils. Can. The Journal of Microbiology, 43, 891-894. http://dx.doi.org/10.1139/m97-130

[18] Sneath, P.H.A. and Sokal, R.B. (1973) Numerical Taxonomy In: The Principles and Practices of Numerical Classification, Freeman WH and Company, San Francisco.

[19] Saeki, Y., Kaneko, A., Hara, T., Suzuki, K., Yamakawa, T., Nguyen, M.T., Nagatomo, Y. and Akao, S. (2005) Phylogenetic Analysis of Soybean-Nodulating Rhizobia Isolated from Alkaline Soils in Vietnam. Soil Science \& Plant Nutrition, 51, 1043-1052. http://dx.doi.org/10.1111/j.1747-0765.2005.tb00143.x

[20] Holt, J.G., Kreig, N.R., Sneath, P.H.A., Staley, J.T. and Williams, S.T. (1994) Brgey’s Manual of Determinative Bacteriology. Williams and Wilkins, Baltimore.

[21] Miličić, B., Delić, D., Kuzmanović, D., Stajković, O. and Jošić, D. (2006) Intrinsic Antibiotic Resistance of Different Bradyrhizobium japonicum and Rhizobium galegae Strains. Romanian Biotechnological Letters, 11, 2723-273.

[22] Sharma, M.P., Srivastava, K. and Sharma, S.K. (2010) Biochemical Characterization and Metabolic Diversity of Soybean Rhizobia Isolated from Malwa Region of Central India. Plant, Soil and Environment, 56, 375-383.

[23] Padmanabhan, S., Hirtz, R.D. and Broughton, W.J. (1990) Rhizobia in Tropical Legumes: Cultural Characteristics of Rhizobium meliloti and Bradyrhizobium spp. Soil Biology and Biochemistry, 22, 23-28. http://dx.doi.org/10.1016/0038-0717(90)90055-5 
[24] Faghire, M., Mohamed, F., Taoufiq, K., Fghire, R., Bargaz, A., Mandri, B., Oufdou, K., Laury, A., Drevon, J.J. and Ghoulam, C. (2013) Genotypic Variation of Nodules’ Enzymatic Activities in Symbiotic Nitrogen Fixation among Common Bean (Phaseolus vulgaris L.) Genotypes Grown under Salinity Constraint. Symbiosis, 60, 115-122. http://dx.doi.org/10.1007/s13199-013-0247-x

[25] Thrall, P.H., Bever, J.D. and Slattery, J.F. (2008) Rhizobial Mediation of Acacia Adaptation to Soil Salinity: Evidence of Underlying Trade-Offs and Tests of Expected Patterns. Journal of Ecology, 96, 746-755. http://dx.doi.org/10.1111/j.1365-2745.2008.01381.x

[26] Nagales, J., Campos, R., Ben-Abdelkhalek, H., Olivares, J., Lluch, C. and Sanjuan, J. (2002) Rhizobium tropici Genes Involved in Free-Living Salt Tolerance Are Required for the Establishment of Efficient Nitrogen Fixing Symbiosis with Phaseolus vulgaris. Molecular Plant-Microbe Interactions, 15, 225-232.

[27] Rathore, M.S., Shekhawat, N.S. and Gehlot, H.S. (2009) Need of Assessing Rhizobia for Their Plant Growth Promoting Activity Associated with Native Wild Legume Inhabiting Aravalli Ranges of Rajasthan, India. Botany Research International, 2, 115-122.

[28] Meghvansi, M.K. (2006) Isolation, Identification and Effectiveness of Rhizobial Strains and Arbuscular Mycorrhizal (AM) Fungi of Soybean Cultivars Grown in Bundi and Udaipur, Rajasthan. PhD Thesis, Maharshi Dayanand Saraswati University, Ajmer.

[29] Harwani, D. (2006) Biodiversity and Efficiency of Bradyrhizobium Strains Are Arbuscular Mycorrhizoal Fungi of Soybean Cultivars Grown in Haroti Region of Rajasthan. PhD Thesis, Maharshi Dayanand Saraswati University, Ajmer.

[30] Rodrigues, C.S., Laranjo, M. and Oliveira, S. (2006) Effect of Heat and pH Stress in the Growth of Chickpea Mesorhizobia. Current Microbiology, 53, 1-7. http://dx.doi.org/10.1007/s00284-005-4515-8

[31] Ahmad, F., Ahmad, I. and Khan, M.S. (2008) Screening of Free-Living Rhizospheric Bacteria for Their Multiple Plant Growth Promoting Activities. Microbiological Research, 163, 173-181. http://dx.doi.org/10.1016/j.micres.2006.04.001

[32] Mortier, V., Holsters, M. and Goormachtig, S. (2012) Never Too Many? How Legumes Control Nodule Numbers. Plant, Cell \& Environment, 35, 245-258. http://dx.doi.org/10.1111/j.1365-3040.2011.02406.X

[33] Ghosh, S., Sengupta, C., Maiti, T.K. and Basu, P.S. (2008) Production of 3-Indolylacetic Acid in Root Nodules and Culture by a Rhizobium Species Isolated from Root Nodules of the Leguminous Pulse Phaseolus Mungo. Folia Microbiol, 53, 351-355. http://dx.doi.org/10.1007/s12223-008-0054-6

[34] Kaur, H., Sharma, P., Kaur, N. and Gill, B.S. (2014) Tapping of Native Bradyrhizobium and Ensifer sp. Diversity for Functional Traits in Soybean [Glycine max (L.) Merrill]. Legume Research, 37, 651-657. http://dx.doi.org/10.5958/0976-0571.2014.00691.2

[35] Hynes, R.K., Leung, G.C.Y., Hirkala, D.L.M. and Nelson, L.M. (2008) Isolation, Selection, and Characterization of Beneficial Rhizobacteria from Pea, Lentil, and Chickpea Grown in Western Canada. Canadian Journal of Microbiology, 54, 248-258. http://dx.doi.org/10.1139/W08-008

[36] Rejili, M., Mahdhi, M. and Ferchichi, A. (2009) Natural Nodulation of Five Wild Legumes in the South Area of Tunisia. Plant Biosystems, 142, 34-39. http://dx.doi.org/10.1080/11263500802633238

[37] de Vasconcellos, R.L.F., da Silva, M.C.P., Ribeiro, C.M. and Cardoso, E.J.B.N. (2010) Isolation and Screening for Plant Growth-Promoting (PGP) Actinobacteria from Araucaria angustifolia Rhizosphere Soil. Scientia Agricola, 67, 743-746. http://dx.doi.org/10.1590/S0103-90162010000600019

[38] Teixeira, F.C.P., Borges, W.L., Xavier, G.R. and Rumjanek, N.G. (2010) Characterization of Indigenous Rhizobia from Caatinga. Brazilian Journal of Microbiology, 41, 201-208. http://dx.doi.org/10.1590/S1517-83822010000100029

[39] Alikhani, H.A., Saleh-Rastin, N. and Antoun, H. (2006) Phosphate Solubilization Activity of Rhizobia Native to Iranian Soils. Plant and Soil, 287, 35-41. http://dx.doi.org/10.1007/s11104-006-9059-6 